\title{
Who IS This Woman, Anyway?: Hildegard Interpreted in the Twenty-First Century
}

\author{
Cynthia Camer on \\ Boston College
}

\section{Introduction}

Hildegard of Bingen (1098-1179), a twelfth-century Benedictine nun, was well-known and well-regarded in her time. She was consulted by many important Church and secular leaders of her era, including Bernard of Clairvaux, Pope Eugene III, and the Holy Roman Emperor Frederick Barbarossa, and was often a source of counsel as well as criticism. Her insight was valued by people from all walks of life, from kings and popes to everyday men and women. Upon her death, she was one of the first people to be considered for canonization under the Roman Catholic Church's relatively new canonization process. ${ }^{1}$ Despite being venerated by her local community and throughout Germany, Hildegard was not canonized as a saint for the universal church, and she was largely forgotten by the wider world.

However, in the twentieth and twenty-first centuries, Hildegard has been rediscovered ${ }^{2}$ and has become an important source of wisdom and inspiration for many, including those interested in the study of theology, history, music, science, medicine, and poetry. Because she was such a remarkable woman, modern theologians have found in her work much that is worthy of consideration. As Barbara Newman explains:

Among the countless "firsts" and "onlies" to her credit, Hildegard was the only woman of her age to be accepted as an authoritative voice on Christian doctrine; the first woman who received express permission from a pope to write theological books; the only medieval woman who preached openly, before mixed audiences of clergy and laity, with the full approval of church authorities; the author of the first known morality play and the only twelfth-century playwright who is not anonymous; the only composer of her era (not to mention the only medieval woman) known both by name and by a large corpus of surviving music; the first scientific writer to discuss sexuality and gynecology from a female perspective; and the first saint whose official biography includes a first-person memoir. ${ }^{3}$

Among the most intriguing rediscoveries is that of Hildegard the theologian. Feminist theologians and historians, in particular, have embraced Hildegard as a woman of authority from

\footnotetext{
${ }^{1}$ This process was formalized in 1173 by Pope Alexander III and confirmed in 1200 by Pope Innocent III.

${ }^{2}$ Hildegard's Vita (the story of her life written by her hagiographers in their attempt to have her canonized) as well as her letters, books, and music have been known since the nineteenth century. In the early twentieth century, she became popular with New Age groups who found her references to Wisdom congenial. Her rediscovery by the scholarly community (for example, studies of her poetry by Peter Dronke) came in the mid-twentieth century and research devoted to Hildegard has grown into a vibrant area for both medievalists and feminists. See Sabina Flanagan, Hildegard of Bingen, 1098-1179: A Visionary Life (New York: Routledge, 1989), xii. See also, Barbara Newman, ''Sibyl of the Rhine,' Hildegard's Life and Times," in Voice of the Living Light: Hildegard of Bingen and Her World, ed. Barbara Newman (Los Angeles: University of California Press, 2008), 4.

${ }^{3}$ Newman, "Sibyl of the Rhine,"1.
} 
a time when women did not have an official voice. ${ }^{4}$ Many feminist thinkers, like Barbara Newman, are particularly drawn to Hildegard's feminine imaging of God as a model for how modern believers can imagine God. Hildegard has recently been embraced by the official hierarchy of the Church and, on May 10, 2012, received "equivalent canonization" and, on October 7, 2012, was declared a Doctor of the Universal Church by Benedict XVI. In making these proclamations Pope Benedict XVI highlights her as a model of leadership within traditional monastic life and as a model of obedience to the church and its hierarchy, bringing a "feminine intelligence" to theology. ${ }^{5}$

Because stories are told about them and they are held up as models for believers, saints are often understood in a variety of ways. Like any saint, Hildegard is portrayed in different ways by the various people who recount her life. By analyzing two instances when Hildegard's story has been taken up by modern interpreters, we find the various ways she has been understood. This study examines the perspective of Barbara Newman, a historian who is particularly interested in Hildegard's theological contributions, and Benedict XVI, who declared her a saint and Doctor of the Church. Each offers a reading of Hildegard that reveals as much about her interpreters as it does about Hildegard the woman.

\section{Hildegard of Bingen: Twelfth-Century Nun}

Despite the fact that Hildegard lived and died almost a thousand years ago, it is possible to know the broad outlines of her life. Because she was a prolific writer, her own accounts of major events in her life survive in her letters, books, and the autobiographical sections of her Vita, the account of her life composed as a part of her cause for canonization. ${ }^{6}$ In addition, because of her reputation for holiness, Hildegard's friends, nuns, and disciples began compiling this Vita- even before she died. Although there are many gaps in what is known about Hildegard, especially her childhood and early adulthood, what is preserved is remarkably rich and detailed.

Hildegard was born in the summer of 1098 in Bermersheim, near the city of Mainz. Her parents, Hildebert of Bermersheim and Mechthild of Merxheim, were of the minor nobility prosperous, landed, and well connected. ${ }^{7}$ As a child oblate, Hildegard was given over to religious life at a young age and was left in the care of Jutta, an anchoress attached to the male monastery at Disibodenberg. Hildegard then took the veil around the age of fifteen, probably in $1112{ }^{8}$ Attracted by Jutta's reputation for holiness, the two women were eventually joined by

\footnotetext{
${ }^{4}$ Catherine M. Mooney, "Voice, Gender, and the Portrayal of Sanctity," in Gendered Voices: Medieval Saints and Their Interpreters, ed. Catherine M. Mooney (Philadelphia: University of Pennsylvania Press, 1999), 7.

5 Benedict XVI. "Saint Hildegard of Bingen (2)," General Audience, Paul VI Hall, September 8, 2010, http://www.vatican.va/holy father/benedict xvi/audiences/2010/documents/hf ben-xvi aud 20100908 en.html (accessed October 28, 2012).

${ }^{6}$ Kathryn Kerby-Fulton, "Hildegard of Bingen," in Medieval Holy Women in the Christian Tradition c.1100-1500, ed. Alastair Minnis and Rosalynn Voaden (Turnhout, Belgium: Brepols Publishers, 2010), 345.

${ }^{7}$ Fiona Maddocks, Hildegard of Bingen: The Woman of Her Age (New York: Doubleday, 2001), 17.

${ }^{8}$ This was an unusual choice - rather than place her in an established convent, Hildegard's parents entrusted her to an anchoress, presumably for the rest of her life. The record is unclear about the exact age of Hildegard's oblation. Traditionally, she is said to have been eight years old when she was enclosed with Jutta. However, the recently discovered Vita Jutta suggests that Hildegard may have lived with Jutta at her family's estate in Sponheim until she was 14 or 15, at which point Jutta, Hildegard, and a widow named Uda took the veil at Disibodenberg. See, Maddocks, The Woman of Her Age, 18-19, 22.
} 
others and the community grew into a convent, although still attached to the male monastery at Disibodenberg. ${ }^{9}$ After Jutta's death, Hildegard was elected mistress of the community and, shortly thereafter, began writing the first of her major works, the Scivias in which she describes and interprets her visions. ${ }^{10}$ Having received approval for her writing from Cuno, the abbot of the monastery at Disibodenberg, Bernard of Clairvaux, and Pope Eugene III, ${ }^{11}$ Hildegard grew into a prolific writer. Against the wishes of Abbot Cuno, Hildegard moved her community of women to a new monastery site at Rupertsberg and eventually established a daughter house at Eibingen. ${ }^{12}$ Hildegard died in September of 1179 at the age of 81.

Throughout her life, Hildegard claimed to see visions. As a child, she would see a bright light and was said to have foreseen what a calf would look like even before it was born. These visions disturbed Hildegard and she did not tell people about them. ${ }^{13}$ While living with Jutta, Hildegard continued to have visions and confided in Jutta who, in turn, consulted with Volmar, a monk from Disibodenberg who served as confessor for both women and later as Hildegard's secretary. It was not until after her election as leader of the female community at Disibodenberg that Hildegard felt commanded by God to reveal her visions. Even still, she hesitated to comply and fell ill, which she interpreted as God's displeasure with her hesitancy. Finally, with permission from Volmar and Cuno, Hildegard began to write an account of her visions, which became her first book, the Scivias.

Words used by Hildegard to describe what she saw, generally referred to as lux vivens, include 'perceptions', 'illumination', 'reflection of the living Light', 'visionary insight'. In contrast to most other visionaries, she 'saw' when she was fully awake, rather than in a state of ecstasy induced by fasting, hysteria or any other mix of psychological and physical conditions. ${ }^{14}$

Hildegard seems to have described her visions as not interrupting her normal sight or hearing, not as hallucinations, trances, or daydreams. Modern scholars note that her account of her visions appears remarkably similar to what many migraine sufferers describe. The light, the visual disturbances, and the sense of certitude she felt about her visions are all characteristic symptoms of migraines. ${ }^{15}$ Whatever the cause of her visions, Hildegard experienced them throughout her life and came to believe that God was using them to speak to and through her. ${ }^{16}$ This understanding of her visions was confirmed for Hildegard when she received official encouragement to write about them from Bernard of Clairvaux and Pope Eugene III; they also believed her visions to be from God.

Hildegard's written corpus, impressive - because of its sheer size and the sophistication of her writing - for anyone of the twelfth-century, encompasses a wide variety of genres. Known to her contemporaries primarily as a seer or visionary, Hildegard's most important works are her three-volume record of her visions: Scivias (or Know the Ways of the Lord), The Book of Life's Merits, and On the Activity of God (or Book of Divine Works). In addition to these, she

\footnotetext{
${ }^{9}$ Flanagan, A Visionary Life, 3.

${ }^{10}$ Ibid., 4.

${ }^{11}$ Maddocks, The Woman of Her Age, 75-76.

${ }^{12}$ Heinrich Schipperges, The World of Hildegard of Bingen: Her Life, Times, and Visions, trans. John Cumming (Collegeville, MN: The Liturgical Press, 1998), 31-32.

${ }^{13}$ Maddocks, The Woman of Her Age, 55.

${ }^{14}$ Ibid., 58.

${ }^{15}$ Ibid., 63.

${ }^{16}$ Flanagan, A Visionary Life, 209.
} 
wrote scientific texts, including The Book of Simple Medicine (or Physica) and The Book of Compound Medicine (or Causes and Cures). She wrote music and a number of other books including two saints' lives - of St. Disibod and St. Rupert - and commentaries on the Benedictine Rule and the Athanasian Creed; in addition, she invented a new language including about 900 words. Alongside all of these, she was a prolific letter writer, corresponding with three popes, two kings, many local nobles and church leaders, monastic communities, and lay people. ${ }^{17}$ Finally, towards the end of her life, she embarked on four unprecedented preaching tours, preaching before monks, nuns, priests and lay people. ${ }^{18}$

After her death, Hildegard's nuns and friends moved quickly towards petitioning for Hildegard's canonization under the new procedures implemented by the papacy. ${ }^{19}$ Towards the end of her life, she had begun to write an autobiographical account of her life, ${ }^{20}$ at the same time, Gottfried, her secretary after the death of Vomar, began writing a Vita. Both of these works were incomplete; Hildegard's memoir covered her life until 1170 and Gottfried's account ended in 1155..$^{21}$ Her last secretary, Guilbert, began a biography of Hildegard but was called back to his monastery in 1180, never finishing the work. Theodoric, a monk, scribe, and librarian, was commissioned to finish the story of Hildegard's life despite not having ever met her. In his work, he stitched together the Vita, combining first-person accounts from Hildegard with thirdperson accounts (sometimes of the same events); he added no new material other than the account of her death. ${ }^{22}$ After the Vita was completed in 1187 , several attempts were made to have Hildegard canonized. These attempts failed; it seems that the dossier was returned for further information or clarification. ${ }^{23}$ Nevertheless, Hildegard was venerated by the people of Germany, was referred to as 'blessed,' and her feast day was listed on local and Roman lists of saints. ${ }^{24}$ Despite never having been formally canonized, Hildegard was recognized as a holy woman and her books were preserved and consolidated (for example in Gebeno's Mirror of Future Times). ${ }^{25}$ It was not until May of 2012, that Pope Benedict XVI formally declared her a

\footnotetext{
${ }^{17}$ Barbara Newman, Sister of Wisdom: St. Hildegard's Theology of the Feminine (Los Angeles: University of California Press, 1987) 11-12.

${ }^{18}$ Barbara Newman, "Three-Part Invention: The Vita S. Hildegardis and Mystical Hagiography" in Hildegard of Bingen: The Context of Her Thought and Art, ed. Charles Burnett and Peter Dronke (London: The Warburg Institute, 1998), 204-205. Newman notes how exceptional this was: "[T] here is no other known case of an orthodox woman who preached formally, publicly, and with unchallenged authority to audiences of both sexes" (p. 205).

${ }^{19}$ At this early stage, the process of canonization involved the submission of a Vita and copies of her correspondence as all of her vast writings to the papacy. This would have been accompanied by records that pointed to her veneration in her home diocese, accounts of visitors to her shrine, and accounts of miracles attributed to her intercession. Barbara Newman, "Hildegard and Her Hagiographers" in Gendered Voices: Medieval Saints and Their Interpreters ed. Catherine M. Mooney (Philadelphia: University of Philadelphia Press, 1999), 30.

${ }^{20}$ Kerby-Fulton, "Hildegard of Bingen," 347. Kerby-Fulton notes that Hildegard may have done this, in part, to control the way certain aspects of her life were told.

${ }^{21}$ Newman, "Three-Part Invention," 190.

${ }^{22}$ Maddocks, The Woman of Her Age, 254. Newman notes that this unusual composition became a new literary style, midway between a classic hagiography and visionary literature. See Newman, "Three-Part Invention," 190.

${ }^{23}$ Flanagan, A Visionary Life, 12. Vauchez notes that in the early years of the canonization process, the feeling of need to have a saint canonized may have not been strong. Papal authorization was seen as a stamp of approval, but perhaps not necessary for a local community already venerating the saint. He also notes that, in these early days, a great many of the causes submitted to the Vatican for canonization were rejected, returned for revision, or not completed. See Anton Vauchez, Sainthood in the Later Middle Ages, trans. Jean Birrell. (New York: Cambridge University Press, 1997), 23, 51.

${ }^{24}$ Maddocks, The Woman of Her Age, 257-258.

${ }^{25}$ Barbara Newman, "Hildegard and Her Hagiographers," 23.
} 
saint of the church through "equivalent canonization" - recognizing her as among the saints of the church even though her cause had not gone through the formal process of canonization. ${ }^{26}$

\section{Sister of Wisolom: Barbara Newman's I mage of Hildegard}

While generally known and venerated in Germany, especially near the original monastery at Rupertsberg and the daughter house at Eibingen, Hildegard fell into relative obscurity outside of Germany after the thirteenth-century attempts to secure canonization had failed. However, the twentieth-century has seen revival in interest in Hildegard. Because she was such a multifaceted and multi-talented woman, there is much for the twenty-first century scholar to find in the life and writings of Hildegard. Music historians have rediscovered Hildegard as a writer of chant and new recordings of her music have been made. ${ }^{27}$ Scientists have noted that Hildegard's scientific works reflect her sensitivity to the natural world and reflects the beginnings of a coherent natural philosophy. ${ }^{28}$ Some of the most enthusiastic devotees of Hildegard, however, are feminists who see her as a twelfth-century model of independence and assertiveness. Feminist theologians also see in Hildegard both a woman working as an authoritative theologian at a time when this activity was reserved for men and a theologian wrestling with feminine images of the divine at a time that when few women explored these kinds of images of God. ${ }^{29}$

Barbara Newman, a scholar of medieval history, literature, and religion, tries to strike a balance in her treatment of Hildegard. On the one hand, she situates Hildegard in the twelfthcentury, not trying to make Hildegard into anything other than what she was. On the other hand, Newman finds a new voice for Hildegard in the twentieth-century, providing modern believers with a new way of appropriating Hildegard's message. Newman identifies Hildegard as a "sapiential" theologian - a member of "the perennial school of Christian thought that centers on the discovery and adoration of divine Wisdom in the works of creation and redemption." ${ }^{30}$ For Newman, Hildegard's genius was in speaking about the traditional theological categories of her time using the feminine images of Eve, Mary, Ecclesia (Church), and Caritas(Love) or Sapientia(Wisdom). "Around them Hildegard developed a richly nuanced theology of the

26 "What is an Equivalent Canonization?" L'Osservatore Romano, May 12, 2012, http://www.osservatoreromano.va/portal/dt?JSPTabContainer.setSelected $=$ JSPTabContainer\%2FDetail\&last $=$ false $=$ \&path=/news/cultura/2012/110q12-Che-cosa-significa-canonizzazioneequipolle.html\&title $=\% 20 \% 20 \% 20$ What $\% 20$ is $\% 20 \% 20$ an $\% 20$ equivalent $\% 20$ canonization $\% 20 \% 20 \% 20 \&$ locale $=$ en (accessed October 29, 2012).

${ }^{27}$ Maud Burnett McInerney, "Introduction: Hildegard of Bingen, Prophet and Polymath," in Hildegard of Bingen: $A$ Book of Essays, ed. Maud Burnett McInerney (New York: Garland Publishing, 1998), xxiii.

${ }^{28}$ Ibid., xxiii.

${ }^{29}$ Caroline Walker Bynum, "Jesus as Mother and Abbot as Mother: Some Themes in Twelfth-Century Cistercian Writing," Harvard Theological Review 70, no 3/4 (July 1977): 257-284. Bynum argues that the use of feminine images for God was increasingly popular among male theologians of the twelfth-century. It tended to develop in cloistered male communities and focused on themes of nurturing and care. For example, Bernard of Clairvaux, a contemporary and supporter of Hildegard, used feminine imagery to describe God, Jesus, Paul, Moses, church prelates, and himself and others as abbots. Drawing particularly on the image of a mother suckling her child, Bernard explores two key ideas: that God, like a mother, cannot forget God's children and that preaching is like breastfeeding in providing the nourishment of good doctrine. However, despite these kinds of explorations by male theologians, they do not reflect either an understanding of equality of men and women or an understanding of these images from a female perspective. Hildegard's exploration of feminine images of God were less earthy and focused on the idea of nurturing; rather, she used feminine images, such as Caritas and Sapientia, as descriptive of the Divine Nature, rather than of how God relates to humanity. See, Newman, Sister of Wisdom, xvii.

${ }^{30}$ Newman, Sister of Wisdom, xvii. 
feminine that belongs wholly to the realm of the symbolic, both in the broadest sense of that term and in the narrower sense allied with medieval allegoresis." 31

Newman argues that Hildegard was deeply influenced by biblical wisdom literature. This wisdom literature was particularly popular among writers in the twelfth-century, many of whom, like Hildegard, were drawn to the portrayal of Wisdom as "God's feminine consort and collaborator in the works of creation." 32 As the personification of God's creative activity in the world, Wisdom became more and more exalted through the later writings of the Hebrew Scriptures and Jewish writings of the intertestamental period (approximately $300 \mathrm{BCE}-100$ $\mathrm{CE}$ ). In the New Testament, Wisdom was identified with Jesus as the "wisdom of God" (I Cor. $1: 24)$ and as the "word of God" (John 1:1).

The sapiential theology of the high Middle Ages, nurtured by the diverse streams of patristic Christology, Marian liturgy, Carolingian humanism, and twelfth-century Platonism, attained its classical zenith in the writings of Hildegard of Bingen. For Hildegard, Sapientia (along with her alter ego, Caritas) was a primary manifestation of the feminine Divine, active in creation, in the Incarnation, and in the ongoing work of sanctification through the virtutes, or divine energies. ${ }^{33}$

Newman argues that Hildegard viewed Wisdom as intimately connected with the mystery of creation and the created world and with Jesus as the centerpiece of creation - the mystery of the Incarnation of Divine Wisdom accomplished through Mary, a woman. ${ }^{34}$ For Hildegard, the Incarnation was central because it is in this event that God as the feminine Divine stooped to humanity. Newman asserts that Hildegard's sapiential theology used feminine images of God to understand a wide variety of aspects of the Divine, such as

the principle of divine self-manifestation; the absolute predestination of Christ; the mutual indwelling of God in the world and the world in God; and the saving collaboration between Christ and the faithful, manifested sacramentally in the Church and morally in the Virtues. In theological shorthand, the feminine divine is associated with the principles of theophany, exemplarity, immanence, and synergy. ${ }^{35}$

Newman traces Hildegard's use of the feminine divine through her writings and argues that Hildegard explored the world of lofty idealized categories: "divine Wisdom and heavenly Love; Eve and Mary as archetypes of fallen and redeemed humanity; Ecclesia, Mother Church, as the graced and vulnerable people of God." 36 In exploring these symbols, Hildegard saw the activities of the feminine Divine in all of life, in the universe, and the individual human being. ${ }^{37}$ As a sapiential theologian, Hildegard's vision of the world was an optimistic one.

Wisdom offers herself freely to those who love her; her theophanies render the knowledge of God both possible and actual... God is accessible and ever-present in the world, and the cosmos is suffused with healing, life-giving energies...All creatures, and

\footnotetext{
${ }^{31}$ Ibid., xviii.

${ }^{32}$ Ibid., 42.

${ }^{33}$ Barbara Newman, God and the Goddesses: Vision, Poetry, and Belief in the Middle Ages (Philadelphia: University of Pennsylvania Press, 2003), 205.

${ }^{34}$ Newman, Sister of Wisdom, 45.

${ }^{35}$ Ibid., 45-46.

${ }^{36}$ Helen J. John, "Hildegard of Bingen: A New Twelfth-Century Woman Philosopher?" Hypatia 7, no. 1 (Winter, 1992): 116.

${ }^{37}$ Newman, Sister of Wisdom, 70.
} 
preeminently the Mother of God, exist from before time and forever in the embrace of Love, whatever their vicissitudes in this sublunary sphere. ${ }^{38}$

However, Newman does recognize Hildegard as a woman of her time, and, as such, Hildegard linked sexuality and asceticism with the feminine. She argues that Hildegard celebrated Eve's fertility and mourned her violation by Satan; she idealized the maternity of Mary but recognized virginity as a sacred calling. While Hildegard had an understanding of sexuality in its clinical form, she believed that only consecrated virginity was a representation of the feminine divine. ${ }^{39}$ Newman recognizes that Hildegard, like the rest of the medieval Church, equated sexuality and sin, leading to a devaluation of marriage and an exaltation of the clerical and religious modes of life.

Interestingly, Hildegard dealt with her sex in her own unique way. According to Newman, "her most radical departure lies in appropriating to herself the Pauline doctrine that divine power is perfected in weakness, and therefore in women." 40 Hildegard did not seek to minimize her femaleness as many of her contemporaries did. She did not seek to "become male," she did not find models in the female prophets of the Bible, and she did not blur the genders into an amorphous "humanity." She did accept the traditional view of male superiority and female inferiority, but she also argued for a complementarity of the sexes expressed in God and humanity. ${ }^{41}$ Despite her traditional stances on gender, sexuality, and female inferiority, she found great value in the exploration of the feminine aspects of God. "But to go further, to argue that her symbolic thinking took the shape that it did because she was a woman, would be to go too far." 42 According to Newman, Hildegard takes her place in the long history of male and female thinkers in this sapiential tradition, but for Hildegard, her sex was not a central or defining category.

In her work, Newman maintains that Hildegard is an extraordinary example of a sapiential thinker from the twelfth-century and a model for theologians in the twenty-first century. To do this, Newman creates an image of Hildegard as a woman of great imagination and creativity. Newman claims that Hildegard is "the first Christian thinker to deal seriously and positively with the feminine as such, not merely with the challenges posed by and for women in a male-dominated world." 43 As such, Newman provides a portrait of Hildegard as a wideranging theological thinker who consciously played with feminine images of God, all while never rejecting the traditional male images of God and male rule of the Church. Newman is careful not to ascribe to Hildegard motivations that would be more expected in modern-day feminists - equality of the sexes, women as authority figures in the world and the church, and so on. And, she notes, Hildegard's theories of gender complementarity are widely rejected by modern feminists because of the tendency to ascribe particular roles and attributes to each gender. Nevertheless, Newman gives us a Hildegard who is a leading thinker about women, God as feminine, and feminine symbols for Jesus, the Holy Spirit, and the Church. Had Hildegard explored these themes as explicitly as Newman does, her twelfth-century contemporaries would

\footnotetext{
${ }^{38}$ Ibid., 251.

${ }^{39}$ Ibid., 252.

40 Ibid., 254.

${ }^{41}$ Ibid., 255.

42 Ibid., 257. Newman situates Hildegard along with other twelfth-century sapiential thinkers: Honorius, Rupert of Deutz, Bernard of Clairvaux, Godfrey of Admont, and Alan of Lille (p. 257). She also traces a history of sapiential theology from the fifteenth century, including such figures as Johannes Trithemius, Jakob Boehme, John Pordage and Jane Leade, William Blake, Goethe, Vladimir Soloviev, and Pierre Teilhard de Chardin.

${ }^{43}$ Ibid., xvii.
} 
have rejected and condemned her. But, for Newman, Hildegard walked a fine line in her explorations of sapiential theology, talking about God as feminine without ever calling the hierarchical and patriarchal structures of her time into question.

\section{Saint and Doctor: Benedict XVI's Image of Hildegard}

As a theologian from Germany, Benedict XVI's interest in Hildegard of Bingen seems natural. As a German, he likely would have heard of her as a child and young adult. As a theologian, he would be aware of her contributions to the theological heritage of his homeland. In fact, as the Cardinal Archbishop of Munich and Freising, he joined the other cardinals, archbishops, and bishops of the German Bishops' Conference in presenting a petition for Hildegard's canonization and appointment as a Doctor of the Church to Pope John Paul II in 1979. At that time, the bishops highlighted Hildegard's sound doctrine, holiness, and authority as a writer. ${ }^{44}$ However, it was not until his own pontificate that Benedict XVI was able to fulfill this petition, naming Hildegard a saint in May 2012 and a Doctor of the Church in October 2012.

Benedict spent significant time presenting Hildegard to the Church. At two general audiences in September 2010, he summarized what he considered to be the most important aspects of Hildegard's life and work. First, Hildegard is described as a Benedictine nun and as a founder of two monasteries. Benedict emphasizes that, as a nun and an abbess, Hildegard was committed to sound religious life: "Her manner of exercising the ministry of authority is an example for every religious community: she inspired holy emulation in the practice of good to such an extent that, as time was to tell, both the mother and her daughters competed in mutual esteem and in serving each other." 45 Second, Hildegard is presented as a recipient of mystical visions and a writer who has been duly authorized by St. Bernard of Clairvaux and Pope Eugene III. Benedict highlights this authorization in particular:

This, dear friends, is the seal of an authentic experience of the Holy Spirit, the source of every charism: the person endowed with supernatural gifts never boasts of them, never flaunts them and, above all, shows complete obedience to the ecclesial authority. Every gift bestowed by the Holy Spirit is in fact intended for the edification of the Church and the Church, through her Pastors, recognizes its authority. ${ }^{46}$

Third, Benedict highlights Hildegard's mystical visions as authentic experiences of God; he is especially enthusiastic of Hildegard's visions that illuminate the "mysterious marriage between God and humanity that is brought about in the Incarnation."47 Fourth, Benedict emphasizes Hildegard as a model for women in the Church; he highlights in particular the special contributions that women can bring to the study of theology:

[T] heology too can receive a special contribution from women because they are able to talk about God and the mysteries of faith using their own particular intelligence and

\footnotetext{
${ }^{44}$ Benedict XVI. "Apostolic Letter Proclaiming Saint Hildegard of Bingen, Professed Nun of the Order of Saint Benedict, a Doctor of the Universal Church," http://www.vatican.va/holy father/benedict xvi/apost letters/ documents/hf ben-xvi apl 20121007 ildegarda-bingen en.html (accessed November 10, 2012), §7.

${ }^{45}$ Benedict XVI, "Saint Hildegard of Bingen," General Audience, Papal Summer Residence, Castel Gandolfo, September 1, 2010, http://www.vatican.va/holy father/benedict xvi/audiences/2010/documents/hf benxvi aud 20100901 en.html (accessed October 28, 2012).

${ }^{46}$ Benedict XVI, "Hildegard of Bingen," September 1, 2010.

${ }^{47}$ Benedict XVI. "Hildegard of Bingen (2)," September 8, 2010.
} 
sensitivity. I therefore encourage all those who carry out this service to do it with a profound ecclesial spirit, nourishing their own reflection with prayer and looking to the great riches, not yet fully explored, of the medieval mystic tradition, especially that represented by luminous models such as Hildegard of Bingen. ${ }^{48}$

Finally, Benedict praises the volume of Hildegard's work, noting in particular her mystical writings in her three books: Scivias, Liber Vitae Meritorum(The Book of Life's Merits), and Liber Divinorum Operum (The Book of Divine Works). He also notes her other writings in the natural sciences and draws particular attention to her musical creations, her letter writing, and her preaching. $^{49}$

Benedict seems to be particularly interested in Hildegard as a faithful daughter of the Church. In an Angelus speech on the Solemnity of the Immaculate Conception of the Blessed Virgin Mary in 2011, he draws a parallel between Mary being "full of grace" (Luke 1:28) and the fullness of grace that is found in the Church. In this context, he cites Hildegard's Scivias in which she speaks of the Church as the virgin mother of all Christians. ${ }^{50}$

Benedict's most complete explanation of his understanding of Hildegard of Bingen is found in his Apostolic Letter officially naming her a Doctor of the Universal Church. In this letter he stresses three key facets of Hildegard: her role as an abbess, as a defender of the Church, and as an authorized mystical writer. First, Hildegard was primarily a Benedictine nun and abbess; Benedict especially notes her vigorous spirit, her fidelity to the Rule of St. Benedict and the founding of the monasteries at Rupertsberg and Eibingen. Second, Hildegard was a tireless promoter of the Church, its faith, and its practices, "promoting Church reform through her writings and preaching and contributing to the improvement of the discipline and life of clerics." 51 Third, as a mystic, Hildegard explored divine revelation and God's love; her "teaching is considered eminent both for its depth, the correctness of its interpretation, and the originality of its views." 52 For Benedict, part of what makes Hildegard's teaching so worthwhile is the authorization that it received during her lifetime from St. Bernard of Clairvaux, the influential and theologically astute Cistercian abbot who was among Hildegard's earliest supporters.

In his Apostolic Letter, Benedict also highlights the key themes of Hildegard's theological writings. In doing this, he seems to take particular care to lay out the orthodoxy of Hildegard's work. Benedict notes that Hildegard traced out the story of God's revelation in creation and in Scripture; he also summarizes Hildegard's anthropology, rooted in the human as image of God, and her ecclesiology of the Church as sacrament of God. For Benedict, the wisdom of Hildegard lies in the fact that she "echoes the teaching of the Apostles, the Fathers and writings of her own day, while [finding] a constant point of reference in the Rule of Saint Benedict." 53

Benedict presents Hildegard as a leader in religious life, a model of ecclesial obedience, and a theologian of feminine intelligence. Her life as a nun and an abbess provides a model for religious life today; she was committed to the spiritual and liturgical life of the monastery and

48 Ibid.

49 Ibid.

${ }^{50}$ Benedict XVI, "Solemnity of the Immaculate Conception of the Blessed Virgin Mary, Angelus," St. Peter's Square, December 8, 2011, http://www.vatican.va/holy father/benedict xvi/angelus/2011/documents/ hf benXvi ang 20111208 en.html (accessed October 28, 2012).

${ }^{51}$ Benedict XVI, “Apostolic Letter," $§ 2$.

52 Ibid., $§ 3$.

53 Ibid., $§ 6$. 
her holiness and effectiveness was affirmed in the vocations she drew to her community. She is a model of what it means to be a defender of the Church; in her letters and her preaching she called everyone, including clerics and popes, to the service of God. And she is a model of how theologians in general, and women theologians in particular, should approach their work - work that serves the needs of the church and is authorized and approved by ecclesial authorities. For Benedict, Hildegard is a model of womanhood and, in her pastoral activity and scientific research, she can illuminate what it means to be a woman in the Church and society. ${ }^{54}$ In sum, Benedict views Hildegard as a model woman - faithful nun, defender of the Church, and feminine theologian:

[W]e think of Hildegard's charismatic and speculative capacity, which offers a lively incentive to theological research; her reflection on the mystery of Christ, considered in its beauty; the dialogue of the Church and theology with culture, science and contemporary art; the ideal of the consecrated life as a possibility for human fulfillment; her appreciation of the liturgy as a celebration of life; her understanding of the reform of the Church, not as an empty change of structure but as conversion of heart; her sensitivity to nature, whose laws are to be safeguarded and not violated. ${ }^{55}$

\section{Conclusion: The M ulti-faceted Hildegard}

A saint is historically constructed; the life of the saint is fashioned and formed to meet the changing needs of the church and society.

Fashioned and authenticated in a complex relationship between clerical authorities and the adherents who spread the holy person's reputation for virtues and miracles, the saint herself or himself is lost to view almost from the beginning. Moreover, the virtue of the saints is such that they are self-effacing and secretive, brave when God trumpets through them but often otherwise modest and inarticulate, bracketing rather than naming their ineffable experience of the Other. Hence saints are not typical. ${ }^{56}$

Like most saints, Hildegard of Bingen has been fashioned and refashioned to fit the changing needs of the variety of cultures and times in which she has been appropriated.

Hildegard's modern retrieval by Barbara Newman provides an interpretation of the saint from a feminist perspective. For Newman, Hildegard is a visionary and theologian of the feminine divine. She argues that Hildegard is the highpoint of a theological tradition that has always been a part of the Church, but never a main component of its theology. Emphasizing the feminine images of God and using feminine symbols for understanding God, creation and the Fall, the Incarnation, and the Church, Hildegard is a model for a modern feminist retrieval of this sapiential theology. For Newman, Hildegard's heroic virtue is in her genius as a theologian of the feminine divine.

A second modern retrieval and reinterpretation of Hildegard is found in the public pronouncements of Benedict XVI. For Benedict, Hildegard is a model of the Benedictine nun and abbess, dutiful and faithful to the Church. Situating his interpretation of her in John Paul II's

\footnotetext{
54 Ibid., $\$ 7$.

55 Ibid., $§ 7$.

${ }^{56}$ Caroline Walker Bynum, "Foreword" in Gendered Voices: Medieval Saints and Their Interpreters, ed. Catherine M. Mooney (Philadelphia: University of Philadelphia Press, 1999), ix.
} 
encyclical on women, Mulieris Dignitatem ${ }^{57}$ Benedict sees Hildegard as a model of womanhood. Her theological anthropology explores an understanding of male-female complementarity and, for Benedict, her status as a woman theologian complements the work of male theologians, bringing a feminine intelligence to her explorations of the divine. For Benedict, Hildegard's heroic virtue is in his understanding of authentic womanhood, which he sees lived out in her life as an abbess and mystic.

Both Newman and Benedict find much of value in Hildegard's work; but, because they approach her with very different assumptions, they arrive at very different understandings of who Hildegard is for the modern world. Because Newman is starting from a feminist perspective, she finds much in Hildegard's writings that resonates with that feminist perspective. Newman is addressing her work to an audience that is likely sympathetic to a feminist approach to the twelfth-century saint and, therefore, she is able to be more radical in her interpretation of Hildegard. On the other hand, because Benedict is starting from a traditional, complementarity model of women, he stresses her role as a dutiful woman and a traditional nun. Benedict's interpretation of Hildegard stresses the ways in which she is aligned with a more traditional understanding of the church. Benedict emphasizes that Hildegard - who has been interpreted by feminists as a creative thinker about the feminine Divine - was an obedient and orthodox woman.

Any interpreter of a saint is going to provide a partial portrait; in stressing some aspects of the saint's life, the interpreter must leave out other aspects. Newman interprets Hildegard using a retrieval of Wisdom theology that has been of particular interest to feminist theologians in the last fifty years. By placing her in this context, Newman emphasizes Hildegard's gifts as a visionary and theologian, but neglects her more concrete work as a nun, scientist, and musician. ${ }^{58}$ On the other hand, Benedict interprets Hildegard using the more traditional categories favored by her earliest hagiographers - as nun, abbess, and mystic. He emphasizes her gifts as a theologian, but largely defines her using much more traditional categories - as a woman authorized by the appropriate ecclesiastical authorities and as a mystic who brings a legitimate, although feminine, interpretation to Scripture and the Church.

So, what does Hildegard have to offer to the church today? Is she a faithful Benedictine nun, founder, and abbess? Is she a theologian of the feminine divine? Is she a theologian with a feminine intellect? Hildegard is not just any one of these interpretations. Even Hildegard herself sought to manage her image. In her writings, she identifies herself as a prophet of God; however, she also took an active role in editing her collection of letters and she wrote her own memoir, all in an attempt to control her legacy and her image. With a woman as complex and multi-talented as Hildegard and with so great a distance in time between her life and the modern church, it is probably impossible to have a completely objective portrait of the saint. And perhaps this is the richness of the saints - they are multi-faceted and they provide new insights whenever their stories are told anew.

\footnotetext{
${ }^{57}$ Benedict XVI, "Hildegard of Bingen," September 1, 2010.

${ }^{58}$ Newman's neglect of these aspects of Hildegard's life is largely confined to her book on Hildegard as a sapiential theologian, Sister of Wisdom. In her other writings on Hildegard, Newman acknowledges and explores many of these other aspects of Hildegard.
} 